\title{
Effect of Different Plant Growth Regulators on Callus Induction from Seeds of Chickpea (Cicer arietinum $\mathbf{L}$.)
}

\author{
Rabha M. Mansur, Ahlam K. Alaila, Rania F. Mohamed, Hamida M.E.Hamad \\ Botany Department, Faculty science, Omar Al-Mukhtar University, Al Bayda - Libya
}

\begin{abstract}
The present study was undertaken to develop a reproducible protocol for efficient in vitro callus initiation of chick pea (Cicer arietinum L.). The main objectives of this present study were to develop the optimal concentrations and combination of auxin and cytokinin for optimized callus induction from seeds as explants. Callus induction was initiated from seeds on MS media supplement, which varied according to the plant growth regulators treatment. Among the growth regulator combinations the highest rate of callus induction (85\%) was observed in MS medium containing $2 \mathrm{mg} \mathrm{L}^{-1}$ of 2,4Dichlorophenoxyacetic Acid (2,4-D), $2 \mathrm{mg} \quad L^{-1}$ Benzylaminopurine (BAP) showed higher percentage ( $63 \%$ ) of callus formation than 1-Naphthaleneacetic acid (NAA), which produced $49 \%$ of callus. There were significant differences in percentage of calli fresh/dry weights (g/jar) on the different initiation ( seven) medium used were the $M S+2,4-D, M S+2,4-D+N A A+B A P$ and $M S+B A P$ had the highest fresh/dry weights (g/jar) in both induction medium.
\end{abstract}

Keywords-Chickpea, explants, in vitro, callus, plant growth regulators and sterilization.

Abbreviations-MS = Murashige and Skoog media; 2, 4-D = 2, 4-Dichlorophenoxyacetic Acid and NAA=1Naphthaleneacetic Acid BAP= Benzylaminopurine .

\section{INTRODUCTION}

Chickpea is an important grain legume cultivated worldwide on more than 12 million hectares [1] and representing an important and available protein, phosphorus, iron and soluble vitamins source. It is the third important food legume of the world [2]. The protein content of chickpea is $22 \%$ [3]. It is usually supplemented with cereals to form balanced diet compared to the other sources of protein, pulses are the cheapest source and have been called "Poor man's meat." Chickpea proteins are rich in essential amino acid "Lysine" which is generally absent in food grain. It has been cultivated from ancient times in the Mediterranean region, in the Middle East and in Indian subcontinent. However, its production is limited due to many biotic and abiotic stresses. Besides providing protein to the diet, legumes have served the purpose of adding valuable nitrogen and organic matter to the soil and provide rich fodders to the milk and draft animals.

Plant tissue culture plays an important role in the production of agricultural and horticultural plants and in the manipulation of plants for improved agronomic performance. In vitro culture of plant cells and tissues has attracted considerable interest in recent years because it provides the means to study the physiological and genetic processes of plants in addition to offering the potential to assist in breeding improved cultivars increasing their genetic variability. Regenerated plants are expected to have the same genotype as the donor plant; however, in some cases, somaclonal variants are found among regenerated plants, e.g. in rice $[4,5,6,7]$. The composition of the medium, mainly the hormonal balance, is another important factor influencing in vitro culture initiation and plant regeneration from somatic embryos [8]. The auxin 2, 4-dichlorophenoxyacetic acid (2, 4- D), alone or in combination with cytokinins, is widely used to enhance callus induction and maintenance [9]. Genetic factors are considered a major contributor to the in vitro response of cultured tissues. Differences in the production of embryogenic calli and regenerated plantlets have been observed, depending on the genotype and explant source [10]. Therefore, plant regeneration from callus culture could provide useful germplasm for plant breeding programmes.

Considering the above facts, the present experiment was undertaken to develop a stable, reproducible, and efficient protocol for callus induction of chickpea in vitro conditions and to identify the medium suitable for seeds callus induction.

\section{MATERIALS AND METHODS}

\subsection{Plant Materials}

The seeds of chickpea used in this study were purchased from the local market healthy and uniform, Al Bayda Libya. The definition of the type of seeds through the Herbarium in the Department of Botany

2.2 Seed sterilization 
Seeds of chick pea were collected as the source of explants. These collected explants were used for the callus induction. The seeds brought to the laboratory and then they were first cleaned thoroughly under a running tap water for $20 \mathrm{~min}$. The explants were immersed in detergent solution and then rinsed three times with autoclaved water. For further surface sterilization of seeds, first ethanol solution $(70 \%)$ at $1.5 \mathrm{~min}$ and seeds were disinfected with $20 \%$ (v/v) Sodium hypochlorite $\left(5.25 \% \mathrm{Cl}_{2}\right)$ containing two drops of a wetting agent Tween 20 solution at $15 \mathrm{~min}$ were applied and then for 35 times explants were immersed in double- distilled water. Due to importance of explants inoculation step in tissue culture technique, this procedure was conducted in the laminar airflow. The material preparation was conducted following by the method of Verma [11] with some alteration.

\subsection{Media preparation}

Different callus induction media consisting of fllu MS basal (Murashige and Skoog) these media supplemented with various concentrations of auxins and cytokines, like), 1- Naphthaleneacetic Acid (NAA), 2,4Dichlorophenoxyacetic Acid (2,4-D) and Benzylaminopurine (BAP) Table 1.

Table.1: Culture media composition (Murashige and Skoog 1962)

\begin{tabular}{|c|c|}
\hline MS+2 $\mathrm{mg} \mathrm{L}^{-1}$ 2,4D & $\begin{array}{c}\mathrm{MS}+2 \mathrm{mg} \mathrm{L}^{-1} 2,4 \mathrm{D}+2 \mathrm{mg} \mathrm{L}^{-1} \\
\mathrm{NAA}\end{array}$ \\
\hline $\mathrm{MS}+2 \mathrm{mg} \mathrm{L}^{-1} \mathrm{NAA}$ & $\mathrm{MS}+2 \mathrm{mg} \mathrm{L}^{-1} 2,4 \mathrm{D}+2 \mathrm{mg} \mathrm{L}^{-1}$ \\
& $\mathrm{BAP}$ \\
\hline $\mathrm{MS}+2 \mathrm{mg} \mathrm{L}^{-1} \mathrm{BAP}$ & $\mathrm{MS}+2 \mathrm{mg} \mathrm{L}^{1} \mathrm{NAA}+2 \mathrm{mg} \mathrm{L}^{-1}$ \\
& $\mathrm{BAP}$ \\
\hline $\mathrm{MS}+0.5 \mathrm{mg} \mathrm{L}^{-1} 2,4 \mathrm{D}+0.5 \mathrm{mg} \mathrm{L}^{-1} \mathrm{NAA}+0.5 \mathrm{mg} \mathrm{L}^{-1} \mathrm{BAP}$ \\
\hline
\end{tabular}

Both media contained $30 \mathrm{~g} \mathrm{~L}^{-1}$ sucrose and the $\mathrm{pH}$ of the culture medium was adjusted to 5.8 after adding $8 \mathrm{~g} \mathrm{~L}^{1}$ agar, then autoclaved for $20 \mathrm{~min}$., at $121^{\circ} \mathrm{C}$ and 1.1 $\mathrm{kg} / \mathrm{cm}^{2}$ pressure. In complete aseptic conditions sterilized seeds were cultured on different callus induction media . All cultures were incubated in a controlled growth chamber, and maintained at $25 \pm 1^{\circ} \mathrm{C}$ at normal condition . Each treatment was represented by 10 cultures and the experiment was repeated three timesthen all cultures were subcultured using same medium after 3 weeks from incubation. three and five weeks from culture, the frequency of explants producing calli $(\%)$, calli fresh/dry weights $(\mathrm{g} / \mathrm{j}$ ar) were recorded respectively.

\section{Calli frequency}

Calli frequency was calculated according the following equation:

$$
\begin{aligned}
& \text { Calli (\%) } \\
& =\frac{\text { Number of explants producing calli }}{\text { Total number of cultured explants }} X 100
\end{aligned}
$$

\section{Calli fresh weight (g/jar)}

Weight of callus was taken from each treatment after five weeks were carefully air dried and recorded as fresh weight (g/jar).

\section{Calli dry weight (g/jar)}

Weight of fresh derived callus taken from each treatment were dried using oven at $40{ }^{\circ} \mathrm{C}$ for $72 \mathrm{~h}$, and recorded as dry weight ( $\mathrm{g} / \mathrm{j}$ ar).

\section{Statistical analysis}

The test of least significant difference (L.S.D) at the level of $0.05 \%$ significance was used to examine differences among treatment means and interactions. Data were statistically analyzed using MSTAT-C software package according to the described method by Freed et al [12].

\section{RESULTS AND DISCUSSION}

Callus induction and initiation of chickpea seeds were observed after 5 days. All seeds formed callus in both induction medium the data of callus induction frequency were recorded from seed explants on seven different media with different levels of plant growth regulators. Callus was first visible within five and seven days in $\mathrm{MS}+2$, 4-D (2 mg L $\left.{ }^{1}\right)$ and MS+ BAP (2 mg L $\left.{ }^{1}\right)$ medium respectively. Callus induction rate, and fresh/dry weights of callus were greatly influenced by both induction medium and seeds explants (Table 2).

Maximum callus induction (85\%) was obtained for explants when seeds were cultured on MS medium enriched with MS+2, 4-D (2 $\mathrm{mg} \mathrm{L}^{-1}$ ) medium. Lowest callus of $(47 \%)$ was observed for seeds, when MS media are supplemented with BAP (2 mg L ${ }^{1}$ ). Rao and Chopra [13] have reported that initiation and development of calli were influenced by the medium and chickpea genotypes. These genotypic differences with respect to callus initiation were also observed in many other plants $[14,15$, and 16]. Among all the growth regulators used, 2,4-D was found to be the most effective growth regulator for chick pea callus induction either when used alone or in combinations with cytokinins. The highest callus induction from hypocotyl was resulted in [17] expriment on MS medium supplimented by $2 \mathrm{mg} \mathrm{L}^{1} 2$, 4-D + 0.5 $\mathrm{mg} \mathrm{L}{ }^{1}$ NAA. This result is same as my resultsimilar to me findings.

As well as the obtained results indicated that using 2-4D alone as only growth regulators in the culture medium enhanced of callus. This coincided with other authors [18] they affirmed that auxins 2,4-D represent one of the most important classes of signaling molecules involved in the regulation of cell division, cell elongation and cell differentiation in higher plants . 
Table.2: Effect of media composition on frequency of callus (\%) and calli fresh and dry weights $(g)$ from seeds of chickpea regardless of the culture conditions.

\begin{tabular}{|c|c|c|c|}
\hline Medium & $\begin{array}{c}\text { Callus induction } \\
(\%)\end{array}$ & \multicolumn{2}{|c|}{ Weight of callus (g) } \\
\cline { 3 - 4 } & & Fresh & Dry \\
\hline $\mathrm{MS}+2 \mathrm{mg} \mathrm{L}^{-1} 2,4 \mathrm{D}$ & $85^{\mathrm{a}}$ & $3.04^{\mathrm{a}}$ & $0.72^{\mathrm{a}}$ \\
\hline $\mathrm{MS}+2 \mathrm{mg} \mathrm{L}^{-1} \mathrm{NAA}$ & $49^{\mathrm{d}}$ & $1.23^{\mathrm{c}}$ & $0.13^{\mathrm{bc}}$ \\
\hline $\mathrm{MS}+2 \mathrm{mg} \mathrm{L}^{-1} \mathrm{BAP}$ & $63^{\mathrm{b}}$ & $2.52^{\mathrm{b}}$ & $0.56^{\mathrm{a}}$ \\
\hline $\mathrm{MS}+2 \mathrm{mg} \mathrm{L}^{-1} 2,4 \mathrm{D}+2 \mathrm{mg} \mathrm{L}^{-1} \mathrm{NAA}$ & $62^{\mathrm{b}}$ & $1.01^{\mathrm{d}}$ & $0.20^{\mathrm{b}}$ \\
\hline $\mathrm{MS}+2 \mathrm{mg} \mathrm{L}^{-1} 2,4 \mathrm{D}+2 \mathrm{mg} \mathrm{L}^{-1} \mathrm{BAP}$ & $62^{\mathrm{b}}$ & $1.27^{\mathrm{c}}$ & $0.33^{\mathrm{b}}$ \\
\hline $\mathrm{MS}+2 \mathrm{mg} \mathrm{L}^{1} \mathrm{NAA}+2 \mathrm{mg} \mathrm{L}^{-1} \mathrm{BAP}$ & $55^{\mathrm{c}}$ & $1.12^{\mathrm{c}}$ & $0.20^{\mathrm{b}}$ \\
\hline $\begin{array}{l}\mathrm{M} \mathrm{mS}+0.5 \mathrm{mg} \mathrm{L}^{-1} 2,4 \mathrm{D}+0.5 \mathrm{mg} \mathrm{L}^{-1} \mathrm{NAA}+0.5 \mathrm{mg} \mathrm{L}^{-1} \\
\mathrm{BAP}\end{array}$ & $57^{\mathrm{bc}}$ & $1.75^{\mathrm{c}}$ & $0.53^{\mathrm{a}}$ \\
\hline
\end{tabular}

Data scored after 3 weeks (for callus induction) and 5 weeks (for weight of callus ) in culture 30 explants per treatment. Means followed by the same letter are not significantly different at the 0.05 probability level.

\section{CONCLUSION}

In conclusion, the results of the present study indicated that seeds have good callus induction ability. The in vitro protocol reported in this study could be used for clonal propagation of chick pea and to obtain competent target tissue for genetic modification.

\section{ACKNOWLEDGEMENTS}

Author wish to thank Botany Department from Omar AlMukhtar University, Al Bayda - Libya for me support and for providing laboratory work facilities.

\section{REFERENCES}

[1] FAOSTAT/FAO. http://faostat.fao.org/default.aspx, accessed December 2010 to March 2012, Rome.

[2] Frankel, O.H., and Hawkes, J.G (eds.) (1975). Crop genetic resources for today and tomorrow. Int. Biological Programmes 2. Cambridge University Press.

[3] Ahmed, N., (1984). Bangladesh Dal Chaser Path, part 1 (A Bengali Booklet). FAO / UNDP project. P. 167.

[4] Lutts, S., Kinet, J.M., and Bouharmont, J., (2001). Somaclonal variation in rice after two successive cycles of mature embryo derived callus culture in the presence of $\mathrm{NaCl}$. Biologia Plantarum. 44: 489495.

[5] Araújo, L.G., and Prabhu, A.S., (2004). Partial resistance to blast in somaclones of rice cultivar CICA-8. Fitopatologia Brasileira. 29: 394-398.

[6] Rasheed, S., Fatima, T., Bashir, T.H., and Riazuddin, S., (2005). Rapd characterization of somaclonal variation in indica basmati rice. Pakistan Journal of Botany. 37: 249-262.

[7] Elanchezhian, R., and Mandal, A.B., (2007). Growth analysis of somaclones generated from a salt-tolerant traditional 'Pokkali' rice (Oryza sativa) Indian Journal of Agricultural Sciences. 77: 184187.

[8] Jiang, W., Cho, M.J., and Lemaux, P.G., (1998). Improved callus quality and prolonged regenerability in model and recalcitrant barley (Hordeum vulgare L.) cultivars. Plant Biotechnol. 15: 63-69.

[9] Castillo, A.M., Egan, B., Sanz, J.M., and Cistue, L., (1998). Somatic embryogenesis and plant regeneration from barley cultivars grown in Spain Plant Cell Reports. 17: 902-906.

[10] Ganeshan, S., Båga, M., Harwey, B.L., Rossnagel, B.G., Scoles, G.J., and Chibbar, R.N., (2003) Production of multiple shoots from thiadiazurontreated mature embryos and leaf-base/apical meristems of barley (Hordeum vulgare). Plant Cell Tiss. Org. Cult. 73: 57-64.

[11] Verma, S., Yadav, K., and Singh, N., (2011). Optimization of the Protocols for Surface Sterilization, Regeneration and Acclimatization of Stevia Rebaudiana Bertoni. American-Eurasian Journal Agriculture and Enviroment. 11(2):221-227.

[12]Freed, R., Einmensmith, S.P.,Guetz, S., Reicosky, D., Smail, V.W., and Wolberg, P., (1989). User's guide to MSTAT-C. An analysis of agronomic research experiments. Michigan State Univ. USA.

[13] Rao, B.G., and Chopra, V.L., (1987). Genotypic and explant differences in callus initiation and maintenance in chick pea. Int. Chickpea Newslett. 17: $10-12$

[14]Lee, S., Kim, B., Won, S., Kim, K., Park, G., Sung, B., Lee, H., and Lee, B., (2004). Factors affecting callus induction and plant regeneration from mature 
seed of zoysiagrass (Zoysia japonica Steud.) J. Kor. Soc. Gras. Sci. 24(1):29-36.

[15] Wang, J., Sun, Y., Hu, J., and Cui, G., (2004). Factors affecting the frequencies of callus induction and plantlet regeneration in maize immature embryo culture. Acta Agron. Sin. 30: 398-402.

[16] Burbulis, N., Blinstrubiene, A., Sliesaravicius, A., and Kupriene., R., (2007). Some factors affecting callus induction in ovary culture of flax (Linum usitatissimum L.). Biologia.53: 21-23.

[17] Kaberi, D., Raihan, M.D., Mahbubur, S.M., and Shaim, A., (2013). Callus induction in chickpea (Cicer arietinum L). Banat Journal of Biotechnology. 5(7): 92-95.

[18] Bennett ,M.J., Marchant, A., May S.T., Swarup, R., (1998). Going the distance with auxin: unraveling the molecular basis of auxin transport. Roy Soci 353: 1511-1515. 